\title{
Imágenes en medicina
}

\section{Una causa infrecuente de hipertensión arterial \\ A rare cause of arterial hypertension}

Mujer de 62 años sin antecedentes de interés que acudió repetidas veces a Urgencias en el último mes por crisis de hipertensión arterial, que se acompañaba de edemas en miembros inferiores. En la analítica únicamente destacaba una hipopotasemia de reciente aparición (2.9 meq//).

Ante estos hallazgos y posterior aparición de dolor en hemiabdomen izquierdo se realizó una tomografía axial computarizada abdominal, que mostró una gran masa heterogénea de $10 \times 10 \mathrm{~cm}$ de diámetro a nivel de la glándula suprarrenal izquierda, así como lesiones hepáticas, pulmonares y óseas sugestivas de enfermedad metastásica. Se realizó una punción aspiración con aguja fina de la masa suprarrenal, que confirmó el diagnóstico de carcinoma de corteza suprarrenal. El estudio hormonal reveló niveles aumentados de DHEA-sulfato (5.345 ngr/ml), cortisol basal $(47,8 \mathrm{ugr} / 100$ $\mathrm{ml})$, cortisol libre urinario $(1.389,05$ ugr/día) y aldosterona (366,46 pgr/ml). Se relacionó la clínica (edemas periféricos, las crisis hipertensivas y la hipopotasemia de reciente aparición) con la naturaleza hiperfuncionante del tumor.

A pesar de iniciar tratamiento quimioterápico con mitotane, la paciente evolucionó de forma desfavorable, falleciendo un mes después en relación con hemorragia en las metástasis hepáticas.

\section{Diagnóstico}

\section{Carcinoma de corteza suprarrenal}

Rebeca Longueira Suárez, Bernardo Sopeña

Servicio de Medicina Interna. Hospital Xeral.

Complexo Hospitalario Universitario de Vigo (CHUVI). SERGAS. Vigo

Como citar este artículo: Longueira Suárez $R$, Sopeña $B$

Una causa infrecuente de hipertensión arterial. Galicia Clin 2012; 73 (2): 70

Recibido: 07/08/2011; Aceptado: 25/10/2011
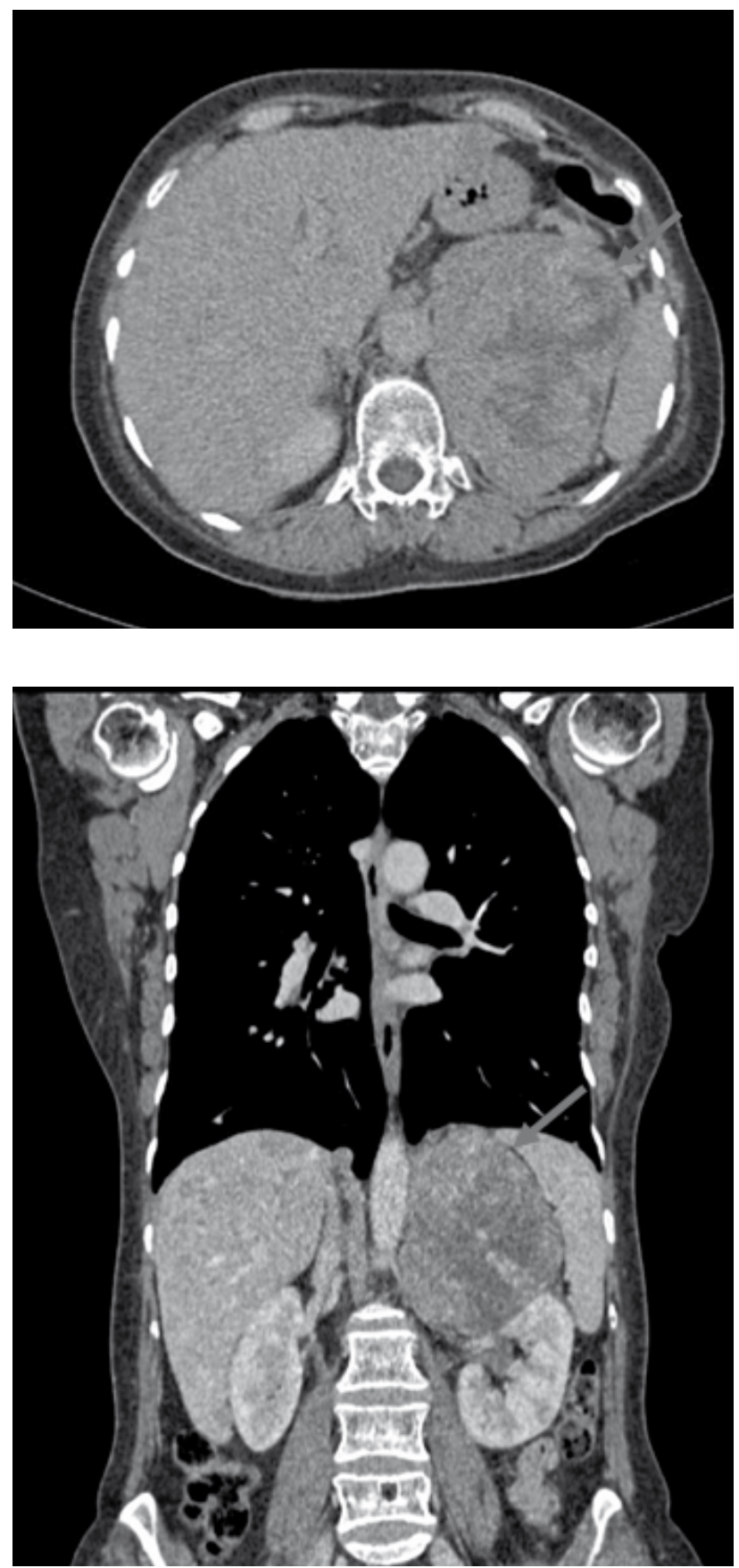